\title{
Instrument Development Sports Risk Management Practice Using Rasch Measurement Model
}

\author{
Ahmad bin Esa ${ }^{1} \&$ Fatimah Mustaffa ${ }^{2}$ \\ ${ }^{1}$ Universiti Tun Hussin Onn Malaysia, Malaysia \\ 2 Institut Pendidikan Guru Malaysia, Malaysia \\ Correspondence: Ahmad bin ESa, Pusat Kokurikulum, Universiti Tun Hussin Onn Malaysia, Malaysia. Tel: \\ 70-607-453-7480. E-mail: ahmad@uthm.edu.my
}

\author{
Received: September 28, 2014 Accepted: March 24, 2015 Online Published: June 5, 2015 \\ doi:10.5539/ass.v1 $1 \mathrm{n} 18 \mathrm{p} 18$ \\ URL: http://dx.doi.org/10.5539/ass.v11n18p18
}

\begin{abstract}
Instruments Sports Risk Management Practices (APRS) was constructed to identify risk management practices among coaches IPG sports in Malaysia. This study was conducted to prove the validity and reliability of APRS by building Rasch model. The respondents comprised of coaches and athletes IPG which represents IPGMs the Games Institute for Higher Education 2013. Validity and reliability of the questionnaire were measured using Winsteps software version 3.69.1.11. The results showed that the reliability index for the item and the respondents are respectively 0.75 and 0.99 . In terms of polarity, each item is capable of measuring APRS coach with the Institute of Teacher Education Malaysia PTMEA CORR value between 0.15 to 0.85 . Incompatibility test items showed no item should be dropped because the outfit mean-square value is in the range of 0.6 to 1.4 and test unidimensionality shows the standardized residual variance was $50.9 \%$, equivalent to the model of $50.9 \%$ with the largest secondary dimension in contrast to the first record variance of $5.6 \%$. APRS capable of measuring constructs built the identification, evaluation, selection and implementation of operations.
\end{abstract}

Keywords: practice, sports risk management, Rasch measurement model

\section{Introduction}

An instrument with features of good reliability and validity should be done to determine the APRS coach IPG. Special Olympics Coaching Guide (SOCG, 2003) explained that risk management is a method to identify risks and develop and implement programs to protect the organization and avoid losses. Coach has the primary responsibility to reduce the risk of entry of the athletes involved in the sport coached. Lecturer of risk management competency involves the knowledge and skills (Bafirman, 2014; Harun, Salamudin, \& Hushin, 2013; ACICR, 2008; Liu, 2008; Zimmerman, 2007; Lachapelle, 2004; SOCG, 2003) covers the preparation, equipment and environment, teaching and competition, the athletes, evaluation, supervision, risk and emergency response model should sound and complete. Risk management practices must be practiced by trainers for creating a situation which is safe and to protect sports trainers from being prosecuted in court for negligence. Also some security aspects such as safety, security themselves and friends as well as safety equipment and regions (Nair, Kumar, \& Ramalu, 2014; Harun, 2012; Sulaiman, 2010; Nord \& Moore, 2008) are important issues and should be taken to ensure that the working environment and atmosphere in sports orderly and safe to avoid accidents resulting in injury and losses (Teng, 2005; Che Lan, 2008; Rund, 2008; Daroji \& Chia, 2012). Because no instruments standard risk management practices, the researchers will conduct research and work to produce instruments of risk management practices sports for the Institute of Teacher Education Malaysia. This study is intended to produce an instrument APRS among IPG coaches in Malaysia with the reliability, validity and produces profiles of respondents using Rasch model.

\section{Method}

APRS instruments involve several stages of construction in which each level is the most important aspect of getting the validity and reliability as well as produce a profile of the respondents. Construction of instruments involves several steps which researchers are divided into three important parts of the design phase, construction phase, and phase confirm the instrument (Cohen dan Swerdlik, 2010). Instrument design phase involves the purpose of developing the instrument, determine the contents of the instrument, determine the constructs and 
sub-constructs. In determining the content of the constructs and sub researchers also obtained four constructs APRs of identification, evaluation, selection and implementation of operations, build the meta-analysis data for each sub constructs of constructs selected as a result of the literature review. The second phase used in the construction of instruments APRS is writing items, the judgment of the expert panel of five expert panels are required to validate the constructs and sub are built, and finally checking items. Final construction phase in the construction of instruments APRS is validation phase where it involves a pilot study. A pilot study conducted on a population that has been set, all samples consisted of coaches and athletes IPG IPG which represents IPGMs the Games Institute for Higher Education in 2013. During this pilot study the researcher uses all samples (purposeful sampling) as used by researchers Jones (2009). The findings of the pilot study, which analyzed the reliability analysis using Rasch model in which it is an interesting model and clearly in the relationship that exists between man and the actions to be observed and evaluated the validity of the analysis, resulting in a problem-solving style profile students based map items after the findings obtained from the analysis of the study (Bond \& Fox, 2007; Lopen, 1996; Rasch, 1980).

\section{Discussion}

\subsection{The Formation of Risk Management Practices Construct}

\subsubsection{Findings Data Analysis Document}

Through document analysis, the researcher obtained data findings as summarized in Table 1 are referred to from this research and foreign researchers construct risk management practices related to sport a competent coach.

Table 1. Formation of the risk management practices construct document analysis

\begin{tabular}{cccccccc}
\hline \multirow{2}{*}{ Number } & $\begin{array}{c}\text { Constructs of Risk } \\
\text { Management Practices }\end{array}$ & $\begin{array}{c}\text { Hronek \& } \\
\text { Spengler's 2002 }\end{array}$ & $\begin{array}{c}\text { Carpenter } \\
2000\end{array}$ & $\begin{array}{c}\text { Fuller } \\
1999\end{array}$ & $\begin{array}{c}\text { Van De } \\
\text { Smissen 1990 }\end{array}$ & $\begin{array}{c}\text { Kaiser } \\
1986\end{array}$ & $\begin{array}{c}\text { Frequency } \\
\text { ratio }\end{array}$ \\
\hline 1. & Identification & $/$ & $/$ & $/$ & $/$ & $/$ & $5 / 5$ \\
2. & Evaluation & $/$ & $/$ & $\mathrm{x}$ & $/$ & $/$ & $4 / 5$ \\
3. & Selection operation & $\mathrm{x}$ & $/$ & $/$ & $/$ & $/$ & $4 / 5$ \\
4. & Implementation & $/$ & $\mathrm{x}$ & $/$ & $/$ & $/$ & $4 / 5$ \\
\hline
\end{tabular}

Based on the analysis of documents obtained through the exploration of the research literature in journals, seminar papers and scholarly publishing, there are four constructs APRs that have been proposed by previous researchers. Based Hronek and Spengler (2002), Fuller (1999), Farmer (1998) and Van Der Smissen (1990), which construct APRS identification, evaluation, selection of operations and implementation.

Kaiser (1986) also noted the same thing, namely to increase the level of identification is important because in this stage it is not possible to treat the risk until the risk can be identified. This opinion is also in line with Ehsani and Versi (2012) who explains that APRS need qualified coaches to achieve good performances in risk management for the organization. Sports leaders and coaches need to be educated in the field of sports and have the training and experience to competently manage these risks implement risk management practices.

\subsubsection{Data Retrieval Interviews}

Structured interviews were conducted with five experts in their respective fields of officers with experience in sports management from the Institute of Teacher Education, Ministry of Education and the Olympic Council of Malaysia. Azizi et al. (2011) found this method to ask the experts very useful in carrying out daily tasks to be able to provide guidance to avoid wrong actions. The findings of the interview data, the researchers conclude in Table 2 below the table benchmarking practices construct a competent risk management based specialist sports coaches.

The result of the interviews with the experts in the field of risk management, a majority agreed to construct APRSs submitted based on the analysis of documents. In their view, the constructs APRSs by the identification, evaluation, selection and implementation of suitable operations practiced by sports coaches. Opinion given by an expert on risk management in line with ACICR (2008), Liu (2008), Zimmerman (2007), Lachapelle (2004) and SOCG (2003) who explains that APRS is used by coaches to improve their knowledge and skills competency in the field of risk management. In addition, risk management practices can have a positive effect on sports programs and reduce losses, as the impact of the risk of accident or negligence in the performance of a task coach.

Harun (2012), Sulaiman (2010) and Nord and Moore (2008) state that APRSs can improve the performance of safety to ensure that sporting environment orderly and safe to avoid accidents resulting in injury. This statement 
is in line with Beale (2005), which states that safety is a priority consideration in implementing any exercise program. Gaines (2007) and Mun (2004) explain that athletes and coaches should also be mindful of the risk management to avoid injuries or accidents for creating a safe sport and protect individuals from the risk of prosecution for negligence. Therefore, risk management practices put forward by previous researchers and agreed upon by experts in the field of risk management is best practiced by coaches. These can be used as practice for creating a safe sport and improve the competence of knowledge, skills and attitude of the coach in sport program with a more confident and effective.

Table 2. Formation of the risk management practices construct expert interviews

\begin{tabular}{llllllll}
\hline Number & Constructs of Risk Management Practices & P1 & P2 & P3 & P4 & P5 & Frequency ratio \\
\hline 1. & identification & $/$ & $/$ & $/$ & $/$ & $/$ & $5 / 5$ \\
2. & evaluation & $/$ & $\mathrm{x}$ & $/$ & $/$ & $/$ & $4 / 5$ \\
3. & selection operation & $/$ & $/$ & $/$ & $/$ & $/$ & $5 / 5$ \\
4. & implementation & $/$ & $/$ & $\mathrm{x}$ & $/$ & $/$ & $4 / 5$ \\
\hline
\end{tabular}

Based on the results of the analysis carried out, it can be concluded that there are four constructs APRS practiced by the coach, the identification, evaluation, selection and implementation of operations. Therefore, each construct APRS has certain dimensions based constructs have been confirmed as the following discussion:

\subsubsection{Criterion Validity of the Instrument APRS}

Table 3 shows the criteria taken into account in determining the validity of the instruments built APRS. According to Wright and Stone (2004), the conditions necessary to determine the validity of the instrument were developed in (i) the use of such studies are able to measure the respondents and also constructs built, as well as the instruments that need to differentiate respondents. (ii) have appropriate items according to the measurements to be measured. Items that are built to be in the range required. According to Bond and Fox (2007) to study the use of a rating scale of instruments that do not have a disorder, as an instrument that facilitates interference-free respondents to select the desired answer, and there is the same probability for a certain category of individuals selected. (iv) the validity unidimensionality also be implemented to ensure that the measurement is performed in one direction only, (Linacre, 2011; 2006).

Table 3. Criteria for the validity of the instrument APRS

\begin{tabular}{cll}
\hline Criterion & \multicolumn{1}{c}{ Statistical info } & \multicolumn{1}{c}{ Result } \\
\hline Validity item & a. Polarity item & All items showed a positive value PTMEA CORR $>0.15$. All \\
Item $=138$ & b. incompatibility item & items show the mean square infit and outfit from 0.6 to 1.4. Rasch \\
& c. PCA & $\begin{array}{l}\text { dimension recorded the variance 50.9\% identical to the model of } \\
50.9 \%\end{array}$ \\
\hline Profile of & $\begin{array}{c}\text { Distribution of respondents } \\
\text { respondents }\end{array}$ & $\begin{array}{l}86.6 \% \text { of respondents gave a high agreement to construct. 13.33\% } \\
\text { of respondents consented to construct low. } \\
\end{array}$ \\
& instruments built APRS & \\
\hline
\end{tabular}

\subsubsection{Instrument Reliability Index APRS}

Table 4 shows the reliability index for APRS instruments for respondents and survey items that have been implemented. The reliability of the respondents were 0.91 and 0.84 items which, according to Bond and Fox (2007) the reliability of more than 0.80 is acceptable stronger. The analysis of both the questionnaire showed strong reliability to be used to measure and identify APRS coach IPG in Malaysia.

Table 4. Reliability and separation of individual and item APRS study

\begin{tabular}{cccc}
\hline \multicolumn{2}{c}{ RESPONDENTS } & \multicolumn{2}{c}{ ITEMS } \\
\hline reliability & separation & reliability & separation \\
0.99 & 9.54 & 0.75 & 2.00 \\
& & Alpha cronbach $=0.99$ & \\
\hline
\end{tabular}

The researcher also looked at the isolation derived from the analysis. According to Linacre (2006) the isolation capability of the respondents in the study. APRS instrument not only has good reliability even the individual isolation index 9:54 and 2:00 high item shows that it is able to make the separation of the respondents. 
Table 5. Rating Scale Instrumen quality criteria (Fisher, 2007)

\begin{tabular}{llllll}
\hline Criterion & Poor & Fair & Good & Very Good & Excellent \\
\hline Person \& Item Reliability & $<0.67$ & $0.67-0.8$ & $0.81-0.9$ & $0.91-0.94$ & $>0.94$ \\
\hline
\end{tabular}

If we refer to the Cronbach alpha value, the person raw score reliability through reliability is 0.99 . Alpha values show good reliability when the minimum value of alpha is 0.90 (Hopkins, 1998). According to Pallant (2001) for an instrument that is newly constructed or early stage research, the alpha value that can be accepted is 0.6 . This finding indicates that the instrument is highly reliable and acceptable.

\subsubsection{Reliability APRS Construct Instruments}

Table 6 shows the reliability and separation indices obtained for each construct. Each construct record high reliability according to Bond and Fox (2007) the reliability exceeds 0.80 is received strong. Index isolation respondents indicated there are 2 parts aptitude identified and Linacre (2005) states that good separation is at or greater than the value of 2.0 .

Table 6. The reliability and construct the separation of APRS

\begin{tabular}{ccccc}
\hline \multirow{2}{*}{ Constructs } & \multicolumn{2}{c}{ reability } & \multicolumn{2}{c}{ separation } \\
\cline { 2 - 5 } & respondents & items & respondents & items \\
\hline Identification & 0.99 & 0.75 & 9.54 & 2.00 \\
Evaluation & 0.99 & 0.75 & 9.54 & 2.00 \\
selection operation & 0.99 & 0.75 & 9.54 & 2.00 \\
Implementation & 0.99 & 0.75 & 9.54 & 2.00 \\
\hline
\end{tabular}

\subsubsection{Validity of Instruments}

According to Linacre (2011) The validity of the item can be determined by using the results of the Rasch model analysis program output. Output is taken into account in the validity of polarity items, by looking at the PTMEA CORR. In addition, other values are also taken into consideration such as individual maps, fitness items, and isolation unidimensionality.

\section{i. Polarity items.}

The analysis of the 138 items showed the PTMEA CORR APRS are all positive, it shows no items in APRS instruments dropped or thrown. PTMEA CORR high value and positive indicates an item is better able to distinguish the respondents, while if it is negative or zero value indicates a linkage between the respondent is inconsistent with the variables or constructs built (Linacre, 2011). PTMEA CORR the positive (ve) proves the item APRS has been developed to measure the construct to be measured.

\section{ii. Fit items}

Compatibility is very important item in the APRS instruments, as with determining the suitability of an item, the validity of each item can be determined. In determining the appropriateness of items, Bond and Fox (2007) pointed out that the mean-square outfit MNSQ each item and the respondent must be located within 0.6 to 1.4. The results showed that all the mean squared outfit items ranged from 0.60 to 1.40 . This explains the items APRS is appropriate (fit) for the outfit items in the range. If the item has a value of more than 1.4 MNSQ, this explains the confusing items and if the item has a value less than 0.6 MNSQ, this is too simple to explain the items expected

\section{iii. Unidimensionality}

Unidimensionality is the most important consideration in the construction of a test or as a measurement tool to ensure the instrument is unidimensi (Linacre, 2010; Aziz, 2010). To ensure that an instrument be unidimensi, the variance should exceed $40 \%$ and the percentage of unexplained variance of the first contrast is less than $10 \%$.

Based on Table 7, the raw variance is explained by mesuares emprikal and 50.9 for the corresponding model value of $50.9 \%$ measured noise level is about $5.6 \%$. This value is found to be far from the maximum regulated limit of $10 \%$ (Aziz, 2010). The findings are explained instrument APRS is unidimensi to have met the criteria set by the Rasch measurement model. 
Table 7. Variance of standardized residuals (in units eigenvalue)

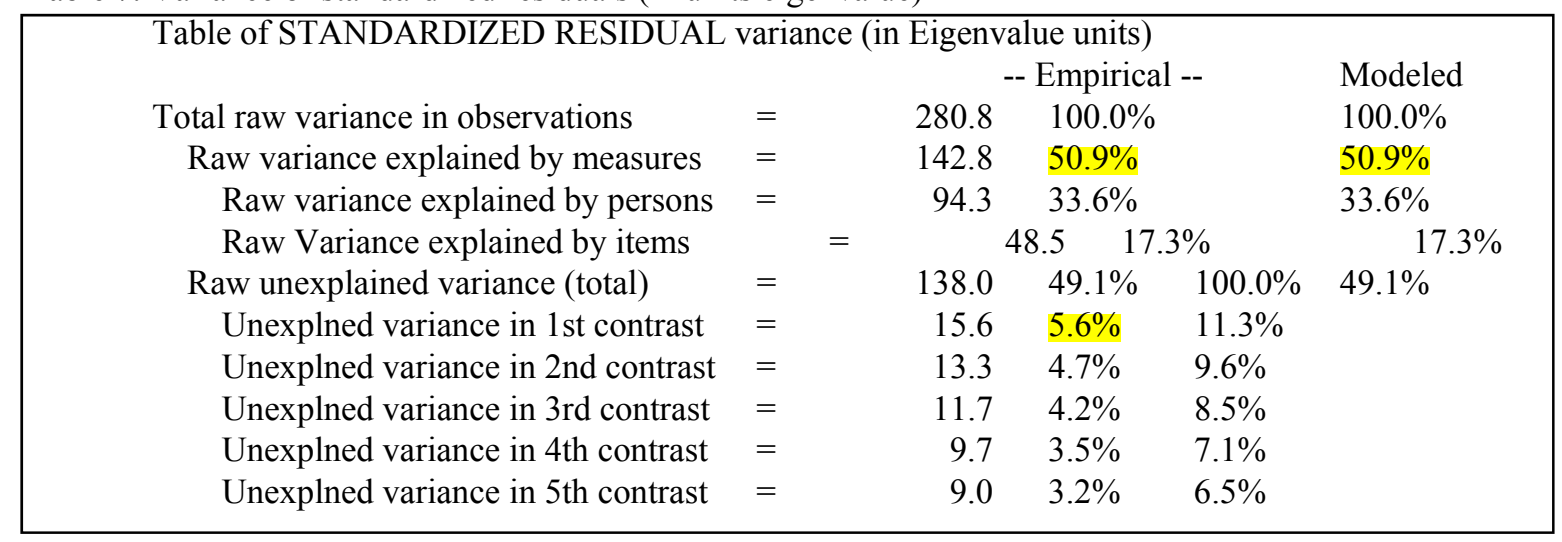

\section{iv. Profile of respondents based on the distribution of item difficulty}

Map items / respondent in Figure 1, indicating whether the instrument is built according to the respondent's ability to give consent (the answer). In the map above, the respondents marked with the notation '\#' and items are described in item code. The letter ' $\mathrm{M}$ ' on the left map shows the average logit for the respondent and on the right is the average logit for items. The letter ' $\mathrm{S}$ ' also means one standard deviation of the item / respondents and ' $\mathrm{T}$ ' indicate two standard deviations of the items / respondent.

According to Wright and Stone (1979), an assessment of the extent to which these items were to interpret a construct with increased intensity rate can be determined by evaluating the extent to which the degree of difference estimated standard error of calibration items exceed those items. They also pointed out that a construct or variable can be considered successful in the interpretation of only those items that are well distributed. When two items overlap with the degree of difference is very little, so the items can not be considered as a measure something different

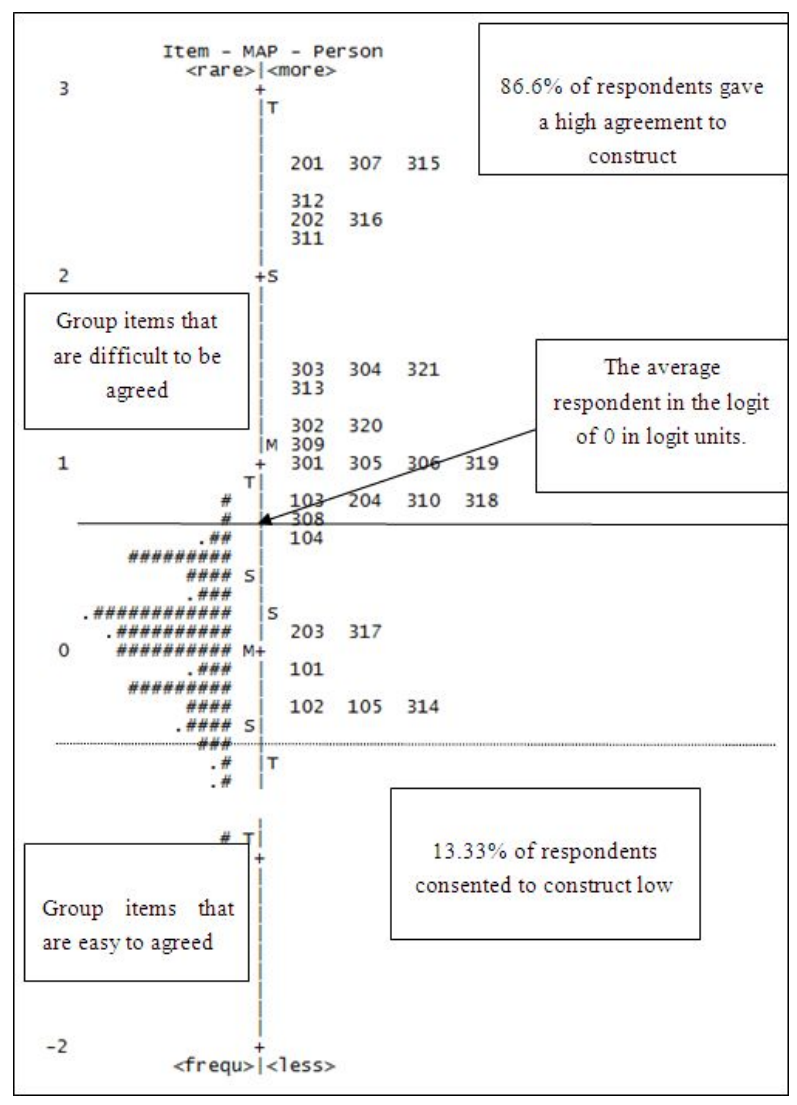

Figure 1. Distribution of item difficulty levels and the ability of respondents 
The results show that $86.67 \%$ of respondents agreed with all the questions raised to them. While $13.33 \%$ of respondents agreed with almost less the question raised. Based on the map item / respondents showed that all items are able to easily agreed that the consent given by the respondents. However, the distribution of items shows the level of difficulty of the items are nearly balanced that there is an item that is tough and easy to finalize.

\section{Conclusion}

Research indicates that the APRS instruments have good validity and reliability. The analysis also found that each construct is built is able to measure risk management practices sports coaches Malaysian Institute of Teacher Education. After the improvements made to the instruments built, APRS instrument is capable of measuring each construct more clearly. This proved to increase the reliability of both the individual and items. This study contributes very significantly to the competent trainers sports management. APRS can be used by any party for determine risk management practices sports coaches Institute of Teacher Education Malaysia.

\section{References}

Abdul Aziz, A. (2010). Rasch Measurement Fundamentals: Scale Construct and Measurement Structure. Kuala Lumpur: Integrated Advance Publishing

ACICR (2008). Safety Guidelines for Physical Activity in Alberta Schools. Canada: Alberta Center for Injury Center and Research.

Bafirman. (2014). Influence of Sports, Physical Education and Health Teacher Professionalism in Developing Students' Character. Asian Social Science, 10(5), 7-11. Retrieved from https://www.questia.com/library/ journal/1P3-3256705671/influence-of-sports-physical-education-and-health

Bond, T. G., \& dan Fox, C. M. (2007). Applying the Rasch Model: Fundamental Measurement in the Human Sciences (2nd ed.). New Jersey: Lawrence Erlbaum Associates.

Carpenter, L. J. (2000). Legal concepts in Sport: Aprimer (2nd ed.). Sagamore Publishiing in cooperation with The american alliance for Health, Physical Education, Recreation and Dance.

Che Lah, N. (2007). HBPE3203 Pendidikan Luar. Selangor: Open University Malaysia.

Cohen, R. J., \& Swerdlik, M. E. (2010). Pscychological Testing and Assessment: An Introduction to Test and Measurement (6th ed.). Boston: McGraw-Hill.

Daroji, I., \& Chia, C. M. (2012). Pendidikan Luar. Selangor: Multimedia

Fisher, W. P. Jr. (2007). Rasch Measurement and the R Statistics Environment. Rasch Measurement Trasactions.

Fuller. (2009). Managing the Risk of Injury in Sport. Journal Sport Medicine, 17(3).

Harun, M. T. et al. (2012). HBPE1203 Kecergasan Fizikal. Selangor: Open University Malaysia.

Harun, M. T., Salamudin, N., \& Hushin, H. Z. (2013). Appraisal of the Sport Facilities Maintenance Management Practices of Malaysian Stadium Corporations. Asian Social Science, 9(12), 93-98. http://dx.doi.org/10.5539/ass.v9n12p93

Hopkins, K. D. (1998). Education and phychological measurement and evaluation. edisi ke-8. Boston: Ally Bacon.

Hronek, B. B., \& Spengler, J. O. (2002). Leal Liability in Recreation and Sport. Champaign, IL: Sangamore.

Jones, S. R. (2009). Constructing Identities at the Intersections: An Autoethnographic Exploration of Multiple Dimensions of Identity. Journal of College Student Development, 50(3). http://dx.doi.org/10.1353/csd.0. 0070

Kaiser, R. A. (1986). Liability and law in recreation, parks, and sports. Englewood Cliffs, NJ: Prentice-Hall.

KPM. (2011). Buku Panduan 1 Murid 1 Sukan. Putrajaya: Bahagian Sekolah, Kementerian Pelajaran Malaysia.

Lachapelle, C. F. (2004). The Risk and Safety Practices in Youth Baseball and Softball. The Florida State University: Tesis Ph.D.

Linacre, J. M. (2005). Test validity anad Rasch measurement: construct. content, etc. Rasch Measurement Transactions, 18(1), 970-971.

Linacre, J. M. (2006). Item Discrimination and Rasch-Andrich Thresholds. Rasch Measurement Transaction, 20(1), 1054 
Linacre, J. M. (2010). A user's guide to WINSTEPS: Rasch-model computer program. Beaverton: Oregon.

Linacre, J. M. (2010). Winsteps ${ }^{\circledR}$ Rasch Measurement Computer Program User's Guide. Beaverton, Oregon: Winsteps.com

Liu, C. Y. (2008). A study of the Relationship between Coach Leadership Behaviour and Junior Tennis Players' Satisfaction. United States Sport Academy: Thesis Ph.D.

Lopez, W. (1996). Communication Validity and Rating Scaler. Rasch Measurement Transaction, 10, 482-483.

Mustaffa, F. (2013). Amalan Pengurusan Risiko Sukan Pensyarah Institut Pendidikan Guru Malaysia. Prosiding $1^{\text {st }}$ UMS International Sport Science Conference. Sabah: Universiti Malaysia Sabah. 1-330.

Nair, H. A. P., Kumar, D., \& Ramalu, S. S. (2014). Organizational Health: Delineation, Constructs and Development of a Measurement Model. Asian Social Science, 10(14).

Nord, N., \& Moore, T. H. (2008). CPSC Releases the "Top Five Hidden Home Hazards" Popular Magnetic Toys on the List of Deadly Dangers. Consumer Product Safety Review, 12(1), 1-2.

Pallant, J. (2001). SPSS survival manual: A step by step guide to data analysis using SPSS for winsows. Version 10. Illionis: Allen \& Unwin.

Rasch, G. (1980). Probailistic Models for Some Intelligence and Attainment Tests. Chicago: The University of Chicago Press.

Rund, J. (2008). Creating and Maintaining Safe College Campuses: A Sourcebook for Evaluating and Enhancing. Journal of College Student Development, 49(3). http://dx.doi.org/10.1353/csd.0.0008

Sulaiman, S. B. (2010). HBEF3403 Pengurusan Sukan dalam Pendidikan Jasmani. Selangor: Open University Malaysia.

Tong, T. B. (2005). Pendidikan Jasmani dan Pendidikan Kesihatan. Kursus Diploma Perguruan Malaysia. Selangor: Longman.

Van der Smissen, B. (1990). Legal liability and risk management for public and private entities. Cincinnati: Anderson Publishing Company.

Wright, B. D., \& dan Stone, M. H. (2004). Making Measures. Chicago, IL: The Phaneron Press.

Wright, B. D., \& Stone, M. H. (1979). Best Test Design, Rasch Measurement. Chicago: MESA Press.

Zimmerman, E. P. (2007). Risk Managenment Practice of Collegiate Athletic Trainers: An Examination of Policies and Procedures. University Huntington, West Virgina: Thesis Ph.D.

\section{Copyrights}

Copyright for this article is retained by the author(s), with first publication rights granted to the journal.

This is an open-access article distributed under the terms and conditions of the Creative Commons Attribution license (http://creativecommons.org/licenses/by/3.0/). 